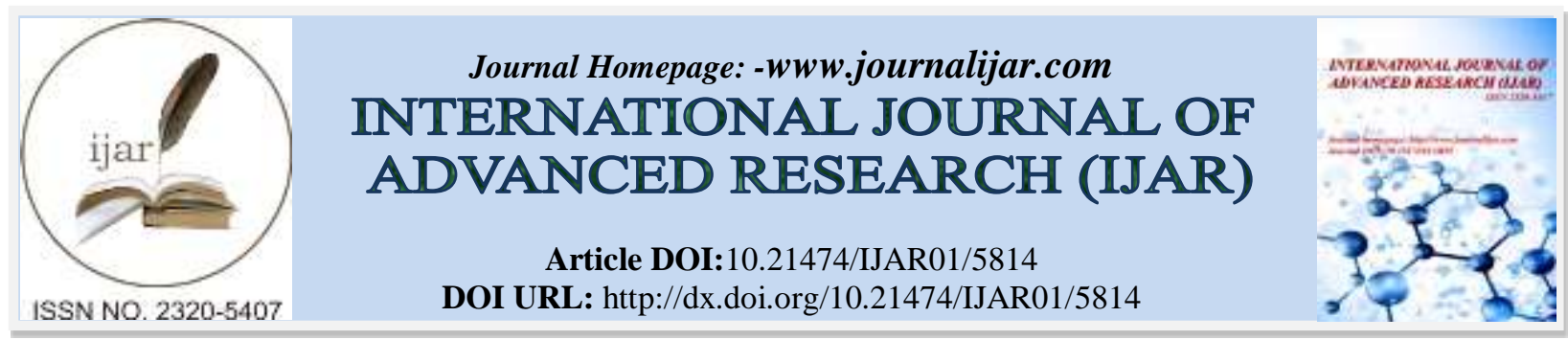

RESEARCH ARTICLE

\title{
DISCRIMINATION OF RETENTION PROBLEM AMONG TRIBAL COMMUNITY OF DOOARS REGION OF WEST BENGAL IN THE LIGHT OF SARVA SHIKSHA AVIJAAN.
}

Gour Sundar Ghosh ${ }^{1}$ and Professor Prasenjit Deb ${ }^{2}$.

1. Assistant Professor, Jalpaiguri A.C. College, \&Scholar, University of Kalyani, West Bengal, India.

2. Head, Department of Lifelong Learning \& Extension, University of Kalyani, West Bengal, India.

\section{Manuscript Info}

Manuscript History

Received: 09 September 2017

Final Accepted: 11 October 2017

Published: November 2017

Key words:-

Drop-out, Socio taboo, BMI, cohort, agglomerated effect, etc.

\begin{abstract}
"Education is neither teaching nor instruction. Instruction is an artificial and limited activity. It influences the child only in a limited time and place. But life-long education goes on influencing an individual throughout his life. Instruction ends in the classroom, but education ends only with life." So, Education is the process of living through a continuous reconstruction of experiences. It is the development of all those capacities in the individual which will enable him to control his society and fulfill his possibilities. This article emphasizes the drainage of human resources among Tribal Community of Dooars Region of West Bengal in the light of SarvaShikshaAvijaan (SSA). This study conducted in two blocks (Matiali\&Nagrakata) of Jalpaiguri, a SarvaShiksha Mission (SSM) district of West Bengal since 2002 to evaluate and assess the reasons behind Dropout Children. To identify the effects, we use structured schedule containing nineteen independent variables viz. Age of respondent $\left(\mathrm{X}_{1}\right)$, Calorie intake value $\left(\mathrm{X}_{2}\right)$, Food intake value $\left(\mathrm{X}_{3}\right)$, Body Mass Index $\left(\mathrm{X}_{4}\right)$, Use of teaching learning material at school $\left(\mathrm{X}_{5}\right)$, Communication to school $\left(\mathrm{X}_{6}\right)$, Attitude of teacher on student $\left(\mathrm{X}_{7}\right)$, Role of school teacher in understanding text book $\left(\mathrm{X}_{8}\right)$, Role of father in understanding text book $\left(\mathrm{X}_{9}\right)$, Role of mother in understanding text books $\left(\mathrm{X}_{10}\right)$, Encouragement of mother towards education $\left(\mathrm{X}_{11}\right)$, Adequate dress during school hour $\left(\mathrm{X}_{12}\right)$, Access to text $\left(X_{13}\right)$, Home environment $\left(X_{14}\right)$,Socio taboo $\left(X_{15}\right)$, Climate factor $\left(\mathrm{X}_{16}\right)$, Financial condition $\left(\mathrm{X}_{17}\right)$, House hold activity $\left(\mathrm{X}_{18}\right)$ and Engagement in productive activity $\left(\mathrm{X}_{19}\right)$ against dependent variable Level of Dropout (Y).
\end{abstract}

Copy Right, IJAR, 2017,. All rights reserved.

\section{Introduction:-}

School education in India is vast and diverse, covering nearly one-and-a-half million schools of diverse sizes, categories, managements, sources of funding, levels and grades taught, mediums of instruction etc., across the length and breadth of the country. The system has been growing and is poised to grow further. The school education has experienced intensive efforts to expand and improve its quality in the recent past. Beginning with OBB during mid1980s, the efforts made include DPEP during mid-1990s, SSA during early 2000s, implementation of mid-day meal scheme and many more. Recently, the Right to Education (RTE 2009) Act was enacted and efforts are being made to harmonies the norms of SSA and RTE 2009 and several State governments are engaged in preparing rules for its 
implementation. In order to plan, implement and monitor these initiatives, reliable, consistent, relevant and up-todate data on several aspects of education is necessary.

For ensuring free elementary education to all children between the age of six years and 14 years, the National Democratic Alliance government launched the SarvaSikshaAbhiyan (SSA) in 2001 and brought a constitutional amendment in 2002 making elementary education a fundamental right. 1 The main objectives of the SSA programme are: (i) all children in school by 2003; (ii) all children complete five years of elementary schooling by 2007; (iii) all children complete eight years of elementary schooling by 2010; (iv) focus on elementary education of satisfactory quality with emphasis on education for life; (v) bridge all gender and social category gaps at the elementary stage by 2007 and at the elementary stage by 2010; and (vi) universal retention by 2010. After five years of implementation of this programme it is time to undertake an appraisal of the performance of this programme in the realization of its objectives. The main aim of S.S.A. (now SSM) is to reduce the existing rate of dropout as well as to enhance the quality of education. Several researches have been taken place in different area of school administration.

In the study Vasavi (2003)viewed that out- of-school children are typically seen as reflecting the persistence of poverty and child labour. And as survey and studies indicate a growth in number of out -of school children debates and talk have focused on capping this tide of out-of -school children. Yet, details about the life condition of these children and the reasons for them to be educationally deprived remain limited. The role of the family, community conditions and orientations, the functioning of schools and impact of the state and interlinks between all these are not well documented or understood. This study drawn on field research conducted in six regions of six states of India and notes the range of conditions, factors and processes that prevent children from attending school. The resulting picture of out-of -school children is one in which education deprivation is contextualized in terms of their life conditions, the functioning of schools and the role of the state. The large and the significant body of out-of school children reflects not only the failure of the state and the education system to ensure universal access to elementary education but also the persistence of a range of social disadvantages which combine to deprive children the opportunity to be educated.

In addition to the dysfunctional of schools, children's experiences in the school determine whether they want to continue to be in school or not. Schools, specifically the teachers, do not take in to account the special circumstances and the multi-disadvantaged circumstances in which many children live and which impact significantly on their orientation and performance in schools. Issues such as their inability to purchase notebooks and stationery, their inability to be presentable land neat and clean, their failure to be regular at classes are issues which teachers chastise and often taunt children about. As noted in the interviews with many children, 'abuse' by teacher, that is, their resorting to frequent and harsh forms of corporal punishment, their indifference, hostility and callousness in the treatment of children often accounted for children dropping out of school. Class differences, where teachers typically come from middle to lower middle classes, and caste differences, where teachers also come from higher caste groups than children, exacerbates social distance between teacher and the students. The failure of teachers to be empathetic to children especially to those who come from economically disadvantages and non-literate families is the single-most importance factor for such high rates of students eliminate from the schools. This is highlighted by the fact that only twenty-four percent of the interviewed families cited that a teacher had ever visited their homes. In most cases, no teacher, member of the education administration or any organization had visited the homes of these children who had dropped out from school. Thus, as Boyden et al (1998) have pointed out, apparent indifference to education is more likely to be symptomatic of a dysfunctional education system than a failure to value education.

While a majority of the dropped-out (86 per cent) and now out-of -school children had attended government schools the rest had attended private schools ( 5 per cent), government aided schools ( 4 per cent) or schools run by NGOs ( 5 per cent). The study also revealed that a large number of children also dropped-out from private schools, which, given the fact that they resided the poor and labouring areas, typically tended to be hastily established private schools run by a single person. In Jaipur, a significant per cent (18 per cent) had attended private schools, in Bangalore, 10 per cent had attended government- aided but privately managed schools, while in Chirala among the fishing community, 19 per cent attended schools run by the NGOs and 7 per cent had been to private schools. In the villages studied, in Madhya Pradesh, all the children who had dropped-out were found to have attended only the village government schools. ${ }^{(1)}$ One of the important works done by Naidu (2000) problems of dropout children and future perspectives of tribal education in south India published in (Journal of educational research and extension vide Vol-39, No.-2, pp 36-46). He finds out that dropouts are very high in number in the interior and distant tribal villages, Female dropouts are more in number than the male dropouts, and in Tamilnadu, female dropouts are high 
compared to other states. In Kerala, percentages of rural dropout children are more than the Kurumbar and Mudugar areas. In Andhra Pradesh, majority of dropout children belong to Kondora, Bagatha and PorangiPraja. In Karnataka, the female dropout is less than male dropout. The percentage of dropout is more in the age group of 10-15 years. Economic necessity and parent's compulsion, absence of Mid-day Meals schemes, improper provision of uniforms and textbooks lead to large scale dropouts in all the states. ${ }^{(2)}$ In the study of Deb and Ghosh (2014) it is found that the wastage of human resources among tribal children has strong bearing with variables like composition of food at school hour, mode of communication to able to school, home environment and social taboo. ${ }^{(3)}$ The dropout issue remains a concern for many school districts, nationally and internationally. Monticel, Cortez, and Cortez (2004) argue that even though research suggests dropout prevention should be a major school reform issue, practitioners continue to focus change efforts on addressing the school performance and student behavioral issues. (4) This tendency to look to schools for solutions to problems that are systemic is a general approach in educational research and reform (Noguera 2003; Fruchter 2007). For example, most dropout prevention and intervention efforts are largely carried out by public schools and related educational entities. ${ }^{(5)}$ The prevention efforts are primarily designed to identify and mitigate behavioral dropout risk factors (Battin-Pearson et al. 2000; Lee and Burkam 2003; Rodriquez and Conchas 2009). These studies and their resultant programs are all well intended and provide definitive insight as to why students dropout. Yet the programmatic emphasis on behavioral indicators (Finn 1993) obscures the larger structural contexts that shape dropout processes. Consequently, little research explores what community-based approaches to dropout prevention look like. For our project, we decided to use community participation as the main framework to explore dropout prevention planning. ${ }^{(9)}$ N. Manandhar and A.B. Sthapit,(2009) carried out a study entitled "Statisticsal Analysis on Causes of Elementary School Dropout in Nawalparasi District of Nepal" with the objective to find out the current dropout rate trend according to grade, age, and sex. 68 numbers of government schools and 24 numbers of private schools were selected by using stratified random sampling technique. The study revealed that maximum dropout rates $10.3 \%$ and $21.9 \%$ were observed in grade I and in the age of six years respectively. The mean age of elementary school dropout children is 8.51 years. Boy's dropout is slightly higher than girl's but there was no significant difference between the dropout and sex of the child. Father's education, occupation, mother's education and total number of children were also negatively correlated with dropout. The study come out with suggestion that to reduce dropout rate of elementary school age children, the parents should be make literate through adult literacy program and made aware and motivated regarding the importance of education. ${ }^{(10)}$

\section{Methodology and Area of Study:-}

The present study is based on intensive house hold survey conducted during February - July, 2013, in one block of the district of Jalpaiguri of the State of West Bengal. The block (PanchayatSamiti), namely Matiali was selected at random, out of 13 blocks in the district (Now 07 Block in Jalpaiguri and another 06 Block in newly setup Alipurduar District). With the help of random sampling method 100dropout students were selected from 5 Gram Panchayat (GP) viz. Bidhan Nagar, IndongMatiali, Matiali Hat, MatialiBatabari-I, MatialiBatabari-II of the Matiali Block.

Similar study is based on intensive individual survey conducted during August, 13 - January, 2014 in another blocks namely Nagrakata was selected at random, out of 07 blocks in the district. With the help of random sampling method 100dropout students were selected from 5 Gram Panchayat (GP) viz. Sulkapara, Champaguri, Looksan, Angrabhasa-I, Angrabhasa-II of the Nagrakata block.

The sample size of this study is 200 among dropout of elementary students. During selection of student, who were dropped either occasionally, seasonally, or permanently. 05 dropout students were selected from each school on random basis. A structure schedule containing 49 different questions / statement / views were placed before each respondent student separately to measure educational activity, health status, etc. and against dependent variable Level of Dropout. These set of 49 questions were ultimately formed 19 consequent variables and 01 predictor variable. Here, in order to explore the problem, different statistical methods like correlation, mean, and Mahalanabis D-square analysis method are used to understand the retention Problem.

\section{Objectives of the study:-}

The main objectives of this specific study are as follows: 
1. To assess the level of retention among students of Matiali block of Jalpaiguri district of West Bengal from some socio-economic, socio-cultural, and other factors associated with elementary school education system;

2. To assess the level of retention among students of Nagrakata block of Jalpaiguri district of West Bengal from some socio-economic, socio-cultural, and other factors associated with elementary school education system;

3. To evaluate the difference of their level retention level of students of two blocks; and

4. To identify the factors responsible for the high and low level of retention.

\section{Result and Discussion :-}

Table - I:-Values of Linear Discriminant Coefficient against 16 casual variables

\section{Sl. No. Variables}

1. $\quad$ Age of respondent $\left(\mathrm{X}_{1}\right)$

2. Calirie intake value $\left(\mathrm{X}_{2}\right)$

3. Food intake value $\left(\mathrm{X}_{3}\right)$

4. Body Mass Index $\left(\mathrm{X}_{4}\right)$

5. Use of teaching learning material at school $\left(\mathrm{X}_{5}\right)$

6. Communication to school $\left(\mathrm{X}_{6}\right)$

7. Attitude of teacher on student $\left(\mathrm{X}_{7}\right)$

8. Role of school teacher in understanding text book $\left(\mathrm{X}_{8}\right)$

9. Role of father in understanding text book $\left(\mathrm{X}_{9}\right)$

10. Role of mother in understanding text books $\left(\mathrm{X}_{10}\right)$

11. Encouragement of mother towards education $\left(\mathrm{X}_{11}\right)$

12. Adequate dress during school hour $\left(\mathrm{X}_{12}\right)$

13. Access to text $\left(\mathrm{X}_{13}\right)$

14. Home environment $\left(\mathrm{X}_{14}\right)$

15. Socio taboo $\left(\mathrm{X}_{15}\right)$

16. Climate factor $\left(\mathrm{X}_{16}\right)$

17. Financial condition $\left(\mathrm{X}_{17}\right)$

18. House hold activity $\left(\mathrm{X}_{19}\right)$

19. Engagement in productive activity $\left(\mathrm{X}_{20}\right)$

\section{Linear Difference of Coefficient}

1.00827

$-.07335$

$-.27943$

$-.06612$

0.35409

0.01780

$-.05140$

$-.19288$

0.21983

$-.36517$

$-.08224$

$-.04599$

0.10211

0.16934

0.32534

$-.00908$

$-.16151$

$-.15993$

0.15862

Table I shows the $\mathrm{D}^{2}$ based statistics on the sixteen variables. This depicted the values of coefficients and Discriminant function of factors which discriminate the student's of two blocks (Matiali\&Nagrakata) of Jalpaiguri district of West Bengal in terms of their level of retention about the activities adopted during SarvaShiksha Mission and its utility towards fulfillment of the objectives of universalisation of elementary education. The tabulated $\mathrm{D}^{2}$ values at 179 degrees of freedom have implied that the 19 variables considered in distinguishing the two levels of student's having high and low retention level were influential.

Table - II:-Means, their differences and 'r' values of variables with respect to retention level.

\begin{tabular}{lcccc}
\hline & $\begin{array}{c}\text { High Level } \\
\mathrm{N}_{1}=100 \\
\text { Mean Value } \\
\text { Variables }\end{array}$ & $\begin{array}{c}\text { Low Level } \\
\mathrm{N}_{2}=100 \\
\text { Mean Value } \\
\text { (Nagrakata) }\end{array}$ & $\begin{array}{c}\text { Mean } \\
\text { Difference } \\
\text { (MD) }\end{array}$ & 'r' value \\
\hline & & & & \\
Age of respondent $\left(\mathrm{X}_{1}\right)$ & $\mathbf{9 . 2 7}$ & $\mathbf{1 0 . 5 2}$ & $\mathbf{1 . 2 5}$ & $\mathbf{- . 6 1 9 8 * *}$ \\
Calorie intake value $\left(\mathrm{X}_{2}\right)$ & 1425.11 & 1445.93 & 20.82 & $.1573^{*}$ \\
Food intake value $\left(\mathrm{X}_{3}\right)$ & 1.93 & 1.99 & 0.06 & -.0230 \\
Body Mass Index $\left(\mathrm{X}_{4}\right)$ & 15.85 & 16.76 & 0.91 & .0495 \\
Use of T.L.M. at school $\left(\mathrm{X}_{5}\right)$ & 2.39 & 2.34 & 0.04 & -.0549
\end{tabular}




\begin{tabular}{|c|c|c|c|c|}
\hline Communication to school $\left(\mathrm{X}_{6}\right)$ & 2.27 & 2.23 & 0.04 & 0.0835 \\
\hline Attitude of teacher on student $\left(\mathrm{X}_{7}\right)$ & 2.22 & 2.24 & 0.02 & 0.0241 \\
\hline $\begin{array}{l}\text { Role of school teacher in } \\
\text { understanding text book }\left(\mathrm{X}_{8}\right)\end{array}$ & 14.67 & 14.61 & 0.06 & $0.2662 * *$ \\
\hline $\begin{array}{l}\text { Role of father in understanding } \\
\text { text book }\left(\mathrm{X}_{9}\right)\end{array}$ & 5.38 & 5.2 & 0.18 & -.0027 \\
\hline $\begin{array}{l}\text { Role of mother in understanding } \\
\text { text books }\left(\mathrm{X}_{10}\right)\end{array}$ & 5.26 & 5.09 & 0.17 & 0.0283 \\
\hline $\begin{array}{l}\text { Encouragement of mother } \\
\text { towards education }\left(X_{11}\right)\end{array}$ & 1.68 & 1.65 & 0.03 & -.1276 \\
\hline $\begin{array}{l}\text { Adequate dress during } \\
\text { school hour }\left(\mathrm{X}_{12}\right)\end{array}$ & 2.45 & 2.49 & 0.04 & -.1254 \\
\hline Access to text $\left(\mathrm{X}_{13}\right)$ & 2.94 & 2.92 & 0.02 & $-.1620 *$ \\
\hline Home environment $\left(\mathrm{X}_{14}\right)$ & 2.93 & 2.85 & 0.08 & -.0023 \\
\hline Socio taboo $\left(\mathrm{X}_{15}\right)$ & 12.79 & 12.7 & 0.09 & -.0179 \\
\hline Climate factor $\left(\mathrm{X}_{16}\right)$ & 5.1 & 4.96 & 0.14 & 0.0219 \\
\hline Financial condition $\left(\mathrm{X}_{17}\right)$ & 1.03 & 1.02 & 0.01 & 0.1299 \\
\hline House hold activity $\left(\mathrm{X}_{18}\right)$ & 1.02 & 2.21 & 1.19 & -.0784 \\
\hline Engagement in productive activity & $\left(X_{19}\right) 1$ & 1.42 & 0.42 & -.1314 \\
\hline
\end{tabular}

\begin{tabular}{lll}
\hline Critical Value $($ One Tail, 0.05$)=+$ or $-0.151(*)$ & $*$ & significant at 5\% \\
Critical Value (Two Tail, 0.01) $=+$ or $-\mathbf{0 . 1 9 7}(* *)$ & $* *$ & significant at 1\%
\end{tabular}

The results in the above table (II) give the mean values and their differences with significance of 20 variables for high and low level of retentively among students of Mal and Matiali blocks of the District of Jalpaiguri of West Bengal. The high retention level means the higher awareness and deeper understanding about the overall activities of SarvaShiksha Mission and on the other hand low retention level means the lower awareness and superficial understanding about the activities of SSM. Here, in this table, high level of retention always does not necessarily to carry the high value and the same is true for the low level retention to carry the low value.

Out of these twenty variables, 4 variables viz. Age of respondent $\left(\mathrm{X}_{1}\right)$, Calorie intake value $\left(\mathrm{X}_{2}\right)$, Role of school teacher in understanding text book $\left(\mathrm{X}_{8}\right)$, Access to text $\left(\mathrm{X}_{13}\right)$ show their significant level of impact in differentiating the high and low level of retention among students of Matiali and Nagrakata blocks.

The mean value of the variable age $\left(\mathrm{X}_{1}\right)$ of students for the two blocks Matiali and Nagrakata are 9.27and 10.52 years respectively. The average age of Nagrakata student is higher than Matiali block. It is significant in explaining differences between high and low level of retention.

The health of the children has great importance in case ofretentively of the children. Here, the health status ismeasured as the summation of the food intake value in termsof calorie intake $\left(\mathrm{X}_{2}\right)$ per day along with the general condition ofhealth. The children of age group 6-14 years has theminimum intake food value in a day is 920 calorie andmaximum 2350 calorie. During the survey, the averageintake food value in a day was found 1766.34 calorie whichindicated the motive why the variable $\mathrm{X}_{2}$ had extensiveattitude on the echelon of dropout. So, calorie intake $\left(\mathrm{X}_{2}\right)$ of Nagrakata block is high (1445.93) than the Matiali block (14.2511). Hence, the variable Calorie intake value $\left(\mathrm{X}_{2}\right)$ has positive impact on the level of retention about dropout to discriminate between its high and low value.

The variables like Role of school teacher in understanding text book $\left(\mathrm{X}_{8}\right)$ shows significant result in this point of view and the mean value for Matiali block is high 14.67 than mean value of students of Nagrakata block 14.61. The role of teacher in Matiali block (understanding text books) plays a prominent responsibility. As the teacher of the child is the key person of the school in terms of learning. 
Analysis of variables like Access to text $\left(\mathrm{X}_{13}\right)$ shows significant result in this point of view and the mean value for Matiali block is high 2.94 than mean value of students of Nagrakata block 2.92. It is not alone sufficient in explaining differences between high and low level of retention. And most of the children in the tribal dominated villages are the first generation learners when a child gets access to his/her text books then s/he will be more interested in learning. In that sense, access to text $\left(\mathrm{X}_{13}\right)$ has had a negative bearing on the dependent variable $\mathrm{Y}$.

Analysis of variables like lack of present elementary education system shows significant result in this point of view and the mean value for Matiali block is high than mean value of students of Nagrakata block. This mean value shows the students of Matiali block more aware than the students of Nagrakata block on the point of shortfall of present elementary education system like lacks in curriculum, discipline, promotion system of students without restriction. Whereas teachers of Nagrakata block were busy to maintain the basic amenities for their students.

Table - III:-Percentage Contribution of Individual Character to the Total Distance Measurement.

\begin{tabular}{llllll}
\hline $\begin{array}{l}\text { Code } \\
\text { No. }\end{array}$ & $\begin{array}{l}\text { Variables } \\
\text { Coefficient }\end{array}$ & $\begin{array}{l}\text { Mean } \\
\text { Difference }\end{array}$ & $\begin{array}{l}\text { Coefficient } \mathbf{x} \\
\text { Mean } \\
\text { Difference }\end{array}$ & $\begin{array}{l}\text { Percentage } \\
\text { Contribution }\end{array}$ & Rank \\
\hline & & & & & \\
$\mathrm{X}_{1}$ & 1.00827 & 1.25 & 1.260338 & 38.12964 & $\mathrm{II}$ \\
$\mathrm{X}_{2}$ & .07335 & 20.82 & 1.527147 & 46.20157 & $\mathrm{I}$ \\
$\mathrm{X}_{3}$ & .27943 & 0.06 & 0.016766 & 0.507224 & $\mathrm{IX}$ \\
$\mathrm{X}_{4}$ & .06612 & 0.91 & 0.060473 & 1.829531 & $\mathrm{~V}$ \\
$\mathrm{X}_{5}$ & .35409 & 0.04 & 0.016488 & 0.498834 & \\
$\mathrm{X}_{6}$ & .01780 & 0.04 & 0.000712 & 0.021541 & \\
$\mathrm{X}_{7}$ & .05140 & 0.02 & 0.001028 & 0.031101 & \\
$\mathrm{X}_{8}$ & .19288 & 0.06 & 0.011573 & 0.350118 & \\
$\mathrm{X}_{9}$ & .21983 & 0.18 & 0.039569 & 1.197113 & \\
$\mathrm{X}_{10}$ & .36517 & 0.17 & 0.062079 & 1.878105 & \\
$\mathrm{X}_{11}$ & .08224 & 0.03 & 0.002467 & 0.074641 & \\
$\mathrm{X}_{12}$ & .04599 & 0.04 & 0.002067 & 0.062542 & VIII \\
$\mathrm{X}_{13}$ & .10211 & 0.02 & 0.002042 & 0.061784 & \\
$\mathrm{X}_{14}$ & .16934 & 0.08 & 0.013547 & 0.40985 & III \\
$\mathrm{X}_{15}$ & .32534 & 0.09 & 0.029281 & 0.885841 & IV \\
$\mathrm{X}_{16}$ & .00908 & 0.14 & 0.001271 & 0.038458 & \\
$\mathrm{X}_{17}$ & .16151 & 0.01 & 0.001615 & 0.048862 & \\
$\mathrm{X}_{18}$ & .15993 & 1.19 & 0.190317 & 2.757749 & \\
$\mathrm{X}_{19}$ & .15862 & 0.42 & -0.06662 & &
\end{tabular}

Table III showed the percentage contribution of each variable to the total discrimination. Out of the 20 variables Calorie intake value (46.20\%), Age of respondent ( 38.12\%), House hold activity (5.75\%), Engagement in productive activity (2.01\%), Role of mother in understanding text books (1.87\%), Body Mass Index(1.82\%), Role of father in understanding text book $(1.19 \%)$, Socio taboo $(0.88 \%)$, Food intake value $(0.50 \%)$, Use of teaching learning material at school $(0.49 \%)$ in a cluster contributed more than 97 per cent towards the total discrimination. Hence, Calorie intake value, Age of respondent, House hold activity, Engagement in productive activity, Role of mother in understanding text books, Body Mass Index, Role of father in understanding text book, Socio taboo, Food intake value, Use of teaching learning material at school have been found to be key discriminators and planners and executors of SarvaShiksha Mission should pay attention on these factors in dealing with the problem of high or low retention level among student's. 


\section{Conclusion:-}

In an attempt to search the socio-economic and environmental factors causing the retention level among the students at the operational stage of RashtriyaMadhyamikShikshaAbhiyan, some prominent factors such as Age of respondent $\left(\mathrm{X}_{1}\right)$, Calorie intake value $\left(\mathrm{X}_{2}\right)$, Food intake value $\left(\mathrm{X}_{3}\right)$, Body Mass Index $\left(\mathrm{X}_{4}\right)$, Use of teaching learning material at school $\left(\mathrm{X}_{5}\right)$, Communication to school $\left(\mathrm{X}_{6}\right)$, Attitude of teacher on student $\left(\mathrm{X}_{7}\right)$, Role of school teacher in understanding text book $\left(\mathrm{X}_{8}\right)$, Role of father in understanding text book $\left(\mathrm{X}_{9}\right)$, Role of mother in understanding text books $\left(\mathrm{X}_{10}\right)$, Encouragement of mother towards education $\left(\mathrm{X}_{11}\right)$, Adequate dress during school hour $\left(\mathrm{X}_{12}\right)$, Access to text $\left(\mathrm{X}_{13}\right)$, Home environment $\left(\mathrm{X}_{14}\right)$, Socio taboo $\left(\mathrm{X}_{15}\right)$, Climate factor $\left(\mathrm{X}_{16}\right)$, Financial condition $\left(\mathrm{X}_{17}\right)$, House hold activity $\left(\mathrm{X}_{18}\right)$ and Engagement in productive activity $\left(\mathrm{X}_{19}\right)$ have been identified. It indicates while low level retention is the flamboyant consequence, observable in the micro-school environment; many more causes are enrooted into the subsystem like, academic achievement in schools, student-teacher relationship, societal role on students' achievement, academic environment in schools, and role of education in promoting students' right etc. To go deeper into the nexus of mutually interdependent subsystem conceding the enhancement of retention level of the students and the fulfillment of the objectives as laid down in SSM, many more factors could have been emerged as path finder in such type of studies.

\section{Reference:-}

1. Vasavi and ArchanaMehendale, "Out of school children: Contexts and Experiences of Education Deprivation", Journal of Educational Planning and Administration, Vol. 17, No 1, January 2003, pp. 69 - 84

2. Naidu, T.S. (2000). Problems of dropout children and future perspectives of tribal education in south India, Journal of educational research and extension, Vol-39, No.-2, pp 36-46.

3. Deb, P., and Ghosh, (2014). "Wastage of Human Resources among Tribal Community of Dooars Region of India." American International Journal of Research in Humanities, Arts and Social Sciences, 14-615, pp-69-74.

4. Monticel, M., J. Cortez, and A. Cortez. 2004. "Dropout Prevention Programs: Right Intent, Wrong Focus, and Some Suggestions on Where to Go from Here." Education and Urban Society 36 (2): 169-188.

5. Fruchter, N. 2007. Urban Schools, Public Will: Making Education Work for All Our Children. New York: Teachers College Press.

6. Battin-Pearson, S., M. Newcomb, R. Abbott, K. Hill, R. Catalano, J. Hawkins, and J. David. 2000. "Predictors of Early High School Dropout: A Test of Five Theories." Journal of Educational Psychology 92 (3): 568-582.

7. Lee, V., and D. Burkam. 2003. "Dropping out of High School: The Role of School Organization and Structure." American Educational Research Journal 40 (2): 353-393.

8. Rodríguez, L. F., and G. Q. Conchas. 2009. "Preventing Truancy and Dropout among Urban Middle School Students: Understanding Community-Based Action from the Student Perspective." Education and Urban Society 41 (2): 216-247.

9. Finn, J. 1993. "Student Engagement and Students at Risk." National Center for Education Statistics. http:// nces.ed.gov/ pubs93/93470a.pdf.

10. Manandhar, N. and Sthapit, (2009). Statistical Analysis on Causes of Elementary School Dropout in Nawalparasi District of Nepal. European Journal of Social Sciences, Volume 24, Number 3. 